\title{
Socio-economic Development of Small Scale Broiler Farmers in Rural Areas of Bangladesh: A Case Study of Mymensingh District
}

\author{
Md. Saiful Islam (Interdisciplinary Graduate School of Science and Technology, Shinshu University) \\ Takashi Sasaki (Shinshu University) \\ L. Mozumdar (Bangladesh Agricultural University)
}

バングラデシュ農村における小規模ブロイラー生産の社会・経済的発展 : マイメンシン地区の事例

$$
\begin{gathered}
\text { エムデイ・サイフル・イスラム（信州大学大学院） } \\
\text { 佐々木隆（信州大学 }) \\
\text { エル・モジュンダー（バングラデシュ農業大学 })
\end{gathered}
$$

バングラデシュでは 1990 年以降ブロイラー生

産者は約 200 倍増加した。それは企業による契 約生産と農家の小規模生産からなるが, 前者は 3 企業のみで他は後者により担われている. 本論 文では第 1 に契約生産が実施されている地域の 調查により, 当初導入された契約システムの失 敗により停滞したこと，そして新たな契約形態

\section{Introduction}

Small scale broiler farming plays a key role in the poverty alleviation, improvement of the food security condition, and socio-economic development of rural and peri-urban communities of developing countries such as Bangladesh. In Bangladesh, the number of broilers was 3540 thousand in 1991, which increased to 260,000 thousand in 2006 (Raha, 2007; Salaque, 2006); the number of poultry farms stood at 787 in 1980, and 148933 in 2006 (DLS, 2007). Bangladesh engages in two types of broiler farming-the contract farming system and the independent farming system. The development of this industry has primarily been brought about by the efforts of independent farmers. The short life cycle of the broilers, the relatively less amount of capital involved, the lesser land requirements as compared to other meat producing animals, and the quick returns have attributed to the popularity of broiler farming among Bangladeshi farmers. Contract farming, however, is still practiced in a few districts near Dhaka, but does not extend to other parts of the country. The contract system of broiler farming has a few unresolved issues and is still under trial; the independent
により縮小した規模で再開されたが，そのシス テムもまだ定着していないことを示した．第 2 に, ブロイラー生産の大半を担っている小規模 生産者を取り上げ，それが農村女性の社会的， 経済的役割に大きな変化をもたらしていること を, ブロイラー生産の 1 中心地であるマイメン シン地区の事例調査を通じて明らかにした。

farming system is therefore dominant in Bangladesh.

The participation of women in different aspects of daily life in Bangladesh is strongly affected by social, cultural and religious norms such as seclusion, segregation, and the veiling (Purdah) of women in public. These restrictions impose limitations on the mobility and participation of women in outdoor work. The practice of Purdah adversely affects the empowerment of women (Biswas, 2004). As a result, their contribution to economic activities is truncated, their opinions are ignored, and their role in the decision making within the family is severely limited. The small scale broiler farming activity, however, is usually conducted in the back-yards of dwellings, which offers women good working conditions: since most of the farms are established around their homestead, women are able to work actively while maintaining religious and social norms. When a woman in the family begins to partake in income generating activities, she is accorded a measure of importance that paves the way to increased participation and contribution in the decision making of the family. Many organizations, in recent times, have come forward to provide assistance to rural women in order to 
help them set up small scale broiler farming units. No systematic study laying particular emphasis on women empowerment has, however, been conducted. Keeping in mind the views stated above, our present study is an attempt to determine and analyze the magnitude of the socio-economic development that has accrued to small scale broiler farmers, and to assess the impact of broiler farming on the empowerment of women in rural areas.

\section{Comparison of the contract farming and independent farming systems}

The contract farming system was first introduced in Bangladesh in 1994 by Aftab Bahumukhi (multipurpose) Farms Limited (ABFL) at Kishoregonj district. The production of broilers under contract entails agreements between farmers and companies that specify the conditions of producing and marketing the broilers. ABFL, a pioneer of the contract farming system, first started broiler production under contract with 20 selected farmers in 1994. In 2002, the number of broiler farms under contract had increased to 650; unfortunately, however, this number remained constant until March, 2004. As mentioned above, the contract involved certain terms and conditions: feed, day old chicks (DOC), medicines, vaccines and technical support were provided by ABFL, while the sheds, land, equipments and labor were provided by the farmers. Finally, broiler sale was managed by ABFL. In the beginning, ABFL provided inputs (feed, DOC, medicine, vaccine) on credit. However, this arrangement did not produce the desired results owing, primarily, to the lack of responsibility, honesty and sincerity on the part of the contracted farmers. ABFL, therefore, had to change their attitude: now, they provide inputs only in lieu of cash payments to educated, honest and solvent farmers who are dedicated to farming and have a good knowledge of broiler rearing. When the new cash contract system was imposed by ABFL, a remarkable number of farmers dropped out. At present (2008), the number of broiler farms operating under cash contracts stands at 450 with an average flock size of 1800 birds, which is the same as that in the credit systems. In credit systems operated by $\mathrm{ABFL}$, the company was providing inputs at retail prices and buying the mature broilers from the farmers at a predetermined price. In the cash system, however, the following clauses are spelt out: (a) the farmers are obligated to buy inputs from the company and sell their birds to them; (b) the prices of, both, the inputs and the mature broilers are established by ABFL, based on the current dealer market prices in Dhaka; and (c) ABFL operates an insurance scheme to cover the farmers against losses arising from the death of chicks owing to disease or other reasons.

Following the ABFL venture, BRAC (Bangladesh Rural Advancement Committee) and Biman Poultry Complex (BPC) entered into contract farming systems of their own near Dhaka city with average flock sizes of 800 and 2500 birds respectively. These two contract systems are almost identical to the ABFL system, barring the following differences: in the BRAC and BPC contract systems, (a) the risk is borne entirely by the farmers, and (b) there are no internal insurance schemes to cover the risk of losses to them. At present, there are about 110,800 broiler farms of different sizes in Bangladesh; while 690 are contract farms (ABFL-450, BRAC-215, and BPC-25). As mentioned earlier, the contract farming system is not a nationwide phenomenon, and is practiced only in a few places.

On the other hand, small scale independent broiler farmers in the rural areas of Mymensingh district are able

Table 1. Contribution of broiler farming to respondents' incomes

\begin{tabular}{|c|c|c|c|c|c|c|}
\hline Occupation & $\begin{array}{l}\text { Average no. } \\
\text { of birds per } \\
\text { annum }\end{array}$ & $\begin{array}{l}\text { Monthly mean } \\
\text { income from broiler } \\
\text { farming }(\mathrm{Tk} .)\end{array}$ & $\begin{array}{l}\text { Mean total } \\
\text { income } \\
\text { (Tk.) }\end{array}$ & $\begin{array}{l}\text { Income from broiler } \\
\text { farming as } \\
\text { percentage } \\
\text { of total income }\end{array}$ & $\begin{array}{c}\text { Land } \\
\text { holding } \\
\text { (hector) }\end{array}$ & $\begin{array}{l}\text { No. of } \\
\text { respondents }\end{array}$ \\
\hline Broiler farming & 4916.67 & 7135.29 & 12411.76 & 57.49 & 0.24 & 17 \\
\hline Crop production & 4000.00 & 5565.22 & 13023.17 & 42.73 & 0.42 & 23 \\
\hline Fisheries & 3797.06 & 4500.00 & 10500.00 & 42.86 & 0.16 & 2 \\
\hline Business & 3684.78 & 5900.00 & 12600.00 & 46.83 & 0.16 & 3 \\
\hline Service & 3787.50 & 5000.00 & 10750.00 & 46.51 & 0.11 & 4 \\
\hline Others & 3000.00 & 5400.00 & 12400.00 & 43.55 & 0.20 & 1 \\
\hline
\end{tabular}

Source: Field Survey, 2008; 1US\$=Tk.69 (September, 2008) 
to economize on the cost of inputs, and sell after negotiating prices with the buyers. This is possible because these farmers have regular access to market information, and relatively easy access to transportation, which allows them to communicate with the urban markets of their region. Farmers in the study area are known to have sold their birds at the farm gate to traders who had come to buy, largely minimizing their transportation costs and reducing the associated risks of broiler mortality during transportation. Moreover, in the study area, farmers are able to easily avail training and technical support facilities offered by the government, NGOs and other private institutions. Mymensingh, as of today, does not have a multipurpose poultry industry big enough to maintain a contractual system. Since a big poultry industry is one of the prerequisites for operating a contract system, farmers prefer the independent broiler farming system: this system, therefore, is dominant in Mymensingh district as well as in almost every other peri-urban area of Bangladesh (source: field survey, 2008).

From the facts mentioned above, the phenomenon of independent small scale broiler farming is rapidly gaining momentum; demonstrated throughout the country, the potential of this activity has been unmistakable. In the following sections, therefore, we focus on the small scale broiler farmers, and analyze the impact of this industry on the empowerment of women.

\section{Outline of the respondents and the contribution of broiler farming}

In order to fulfill the objectives of the study, the Sadar Upazilla of Mymensingh district was selected, deliberately, due to its concentration of broiler farms. In fact, the poultry development process in Mymensingh district was initiated in 1976; thereafter, broiler farming in rural areas gathered momentum and started growing rapidly after 1990 (Ahmed, 2008). The number of broiler farms in Mymenshingh district was 100 in 1990, which increased to 1254 in September, 2008. The number of broilers produced shot up from 53,700 in 1990 to $1,198,274$ in September 2008. Similarly, in the Sadar Upazilla of Mymensingh district, the number of broiler farms and the number of broilers were, respectively, 8 and 4,800 in 1990, which had increased to 126 and 88,400 in September, 2008 (DLO, 2008). The small scale broiler farm owners formed the population of the present study. Out of 126 broiler farms, 50, which reared at least 300 and not more than
2000 broilers per cycle, were selected. This study was based primarily on the set of field-level primary data collected from the respondents. The data was collected during June-September, 2008, on a regular basis by the researcher himself. The primary sources of data were a combination of quantitative and qualitative methods such as interviews using structured and pre-tested interview schedules, focus group discussions and participants' observations, etc.

Table 1 shows an outline of the respondents and the contribution of broiler farming to the respondents' incomes. The average number of birds was highest (4916.67) for those respondents who were engaged in broiler farming as their main occupation. Their monthly gross income from broiler farming was also higher in comparison with all other occupational groups, though the total income was highest for those respondents whose main occupation was crop production. Fifty seven percent of the total income of the broiler farmer came from broiler farming. Income from broiler farming was significant, too, for respondents who belonged to other occupational categories, ranging from around 42 to 47 percent (Table 1). It is remarkable to note that farmers whose main occupation is broiler farming earned more than half of their total income from broiler farming. The scenario is reversed for farmers whose main occupation is crop production. This is, perhaps, due to the differences in size of the land holdings and the number of birds. Here, the term "main occupation" implies that more than half of a family's income is generated from that particular engagement. Further, as shown in Table 2, the total labor hours per day stood at 5.82 , of which 19.59 percent was contributed by adult females. Bangladeshi women face intense social and religious restrictions in working outside their homes. As a result, they are reluctant to work in the crop fields. A potentially valuable contribution from the women's work force is thus squandered away. Our study reveals that adult female members of the family spend a considerable amount of time each day in broiler-rearing activities such as feeding, watering, cleaning, etc. Our study highlights the possible significance of increased broiler farming in that it might be an important means of utilizing the labor of women to increase family incomes and enhance the levels of prosperity. Thus, taking to broiler rearing has certainly increased the incomes of rural families; moreover, it has also offered rural women the opportunity to work in the field of broiler farming.

In general, increase in the income levels results in the 


\section{Table 2. Employment opportunities for family} members

\begin{tabular}{l|c}
\hline \hline Categories & Working hours/day \\
\hline Adult male & 4.08 \\
\hline Adult female & 1.14 \\
\hline Children & 0.60 \\
\hline Total & 5.82 \\
\hline
\end{tabular}

Source: Field Survey, 2008

improvement of living standards. Improvements are observed, initially, in the quality of the food intake, and then, in the prospects of the children's education. Among the respondents, the quality and quantity of food intake were found to have undergone positive changes after (during the period of survey, 2008) their trysts with broiler farming. For example, the weekly consumption of pulses, milk, meat, eggs, vegetables and fish by broiler farmers increased by $48.70 \%, 33.33 \%, 58.90 \%, 77.88 \%$, 30.90\%, and $21.03 \%$, respectively; daily rice consumption levels, too, rose by $10.45 \%$ after the initiation of broiler farming. It is likely that increased purchasing ability is mainly responsible for these changes. Additionally, the broiler farmers culled and consumed birds having less sale value- $\mathrm{a}$ factor that improved their nutrient intake. School-going boys and girls among the respondents had increased by $50 \%$ and $74.29 \%$, respectively. Increased awareness and a greater ability to bear expenses were the main reasons behind the better schooling of children.

\section{Broiler farming and empowerment of women in rural areas}

\section{(1) Participation in decision making}

What is the degree of participation of women in income generating activities and to what extent are they empowered through their involvement in broiler farming? Table 3 shows the changes in the role of women as participants in the family's decision making processes before and after their stint with broiler farming. In all aspects of decision making, the number of instances where wives are the main decision makers or co-decision makers with their husbands has increased. Increased income and the participation of both husband and wife in income-generating activities may have increased the Decision Making Index (DMI), especially in the cases of marriage of son/daughter and the education of their children. It may be noted here that child marriage is a great social menace in Bangladesh, and traditionally, in rural families, boys are preferentially schooled while the education of girls is treated as a matter of secondary importance; the opinions of the wives in these matters is generally not accommodated. Table 3 demonstrates the fact that this situation has begun to change, and women now have the ability to take decisions concerning all aspects of household affairs. This is an important indicator of the empowerment of women. While it has hitherto been common in Bangladeshi society for men to have been the only source of income, the increasing contribution of women to the family earnings through small scale broiler farming has certainly empowered them in the context of their roles within their families.

\section{(2) Decision making with respect to provided working hour in broiler farming}

Table 4 presents the working hours devoted to broiler farming by women with different primary occupations. These working hours vary, too, depending on the type of farm and farm size. Table 4 reveals that the wives of farmers whose main occupation is broiler farming, and who, consequently, have the most birds, spend more time ( 2.2 hours/day) on the activity than women from households that are primarily dependent on crop production or service for their income. This indicates that as opposed to rearing a small flock as a subsidiary occupation, women have the opportunity to supply more labor when allowed to work with larger broiler flock sizes. The pattern also signifies that broiler farming is a great opportunity for women to engage in income generation, which in turn helps them find solidarity and empowerment within their families. The women covered in this study treated broiler farming as their first opportunity to work around the year while maintaining religious and social norms. In croprelated work, on the other hand, women work only twice a year for approximately $2-4$ weeks. An analysis was performed to establish the relationship between the number of decision making affairs (for decision making affairs, see Table 3), the person (wife or husband) who is the primary decision maker, and the number of women's working hours (in broiler farming) in each case- shown in Table 5.

Table 5 indicates that women were empowered to the extent of being the primary decision maker in 5-6 affairs when they provided 2.2 hours/day to broiler rearing. This pattern of time allotment by women signals that spontaneous participation had increased their belongingness and therefore, they were ready to exert and supply more labor for their farms. Therefore, gradually, with increased 
Table 3. Participation in decision making by decision making affairs

\begin{tabular}{|c|c|c|c|c|c|c|c|c|c|}
\hline \multirow{3}{*}{$\begin{array}{l}\text { Main decision maker } \\
\text { in the family } \\
\text { Decision making affairs }\end{array}$} & \multicolumn{9}{|c|}{ Frequency } \\
\hline & \multicolumn{4}{|c|}{ Before broiler farming } & \multicolumn{4}{|c|}{ After broiler farming } & \multirow{2}{*}{$\begin{array}{c}\text { Change of } \\
\text { DMI }\end{array}$} \\
\hline & Husband & $\begin{array}{l}\text { Husband } \\
\text { and Wife }\end{array}$ & Wife & DMI & Husband & $\begin{array}{l}\text { Husband } \\
\text { and Wife }\end{array}$ & Wife & DMI & \\
\hline Education of children & 31 & 12 & 7 & 0.52 & 20 & 19 & 11 & 0.82 & 0.30 \\
\hline Household expenditure & 29 & 17 & 4 & 0.50 & 21 & 23 & 6 & 0.70 & 0.20 \\
\hline Marriage of son/daughter & 25 & 22 & 3 & 0.56 & 15 & 26 & 9 & 0.88 & 0.32 \\
\hline Family planning method & 15 & 35 & 0 & 0.70 & 6 & 40 & 4 & 0.96 & 0.26 \\
\hline Business issue & 36 & 9 & 5 & 0.38 & 24 & 19 & 7 & 0.66 & 0.28 \\
\hline House repairing & 22 & 20 & 8 & 0.72 & 13 & 28 & 9 & 0.92 & 0.20 \\
\hline Total DMI & \multicolumn{4}{|c|}{3.38} & \multicolumn{5}{|c|}{4.94} \\
\hline Average DMI & \multicolumn{4}{|c|}{0.56} & \multicolumn{5}{|c|}{0.82} \\
\hline$\%$ change (Average) & \multicolumn{9}{|c|}{46.43} \\
\hline
\end{tabular}

Source: Field Survey, 2008; Note: DMI $=\frac{\text { Husband } * 0+\text { Husband and wife } * 1+\text { Wife } * 2}{\mathrm{~N}(\text { Number of Respondents })}$

Table 4. Working hours of women in broiler farming according to main occupations

\begin{tabular}{c|c}
\hline \hline Occupation & Women's working hours/day \\
\hline Broiler & 2.2 \\
\hline Crop & 1.5 \\
\hline Service & 1.0 \\
\hline
\end{tabular}

economic responsibility, the empowerment of women has been extended to a number of different decision making affairs. On the other hand, when the husband was the main decision maker, the wives' participation under their husbands' imposition was not as satisfactory. This indicates that a mutual understanding and accommodation of the opinion of both husband and wife is necessary to ensure efficient utilization of women's labor in broiler farming. This corroborates our finding that the level of empowerment of women and their participation in the decision making process depends on how much time they are spending in broiler farming (Nielsen, 2003).

\section{(3) Decision making and pattern of improvement in}

\section{living standards}

When women participate in the decision making process as primary decision makers, what are the changes that take place in their families? Table 6 shows the difference between the wife (as PDM) and the husband (as PDM) while buying household assets. Assets are important items of household expenditure, and their balanced acquirement and utilization is important for income generation and a prosperous life. In Bangladesh, women in general are responsible for handling household activities while the husband has remained the decision maker while buying assets. Table 6 evinces that there is a noticeable difference in the pattern that wives (as PDM) and husbands (as PDM) follow in their respective efforts to improve their standards of living. It clearly indicates that when wives are empowered as primary decision makers, their families prefer to buy almirahs, chairs-tables, sewing-machines, dining tables, etc. Women in rural areas have been found to lay a strong emphasis on buying sewing machines in order to earn additional income by selling self-made cloth to their neighbors, and also cut down on the cloth-making costs of their family members. On the other hand, husbands prefer to buy items like bicycles, mobile phones, etc. The data also attests that husbands derive more satisfaction from buying television sets and land than their wives. Husbands have a greater interest in buying permanent assets like land, needed to

Table 5. Relationships between primary decision makers (PDM), the number of decision making affairs, and the number of women's working hours

\begin{tabular}{l|c|c|c|c}
\hline \hline \multirow{2}{*}{ Working hours/Decision making affairs } & \multicolumn{3}{|c}{ Number of decision making affairs } \\
\cline { 2 - 5 } & None & $1 \sim 2$ & $3 \sim 4$ & $5 \sim 6$ \\
\hline When wife is the primary decision maker (Working hours of wife) & - & 1.0 & 1.3 & 2.2 \\
\hline When husband is the primary decision maker (Working hours of wife) & - & 1.0 & 1.0 & 0.92 \\
\hline
\end{tabular}


Table 6. Participation in decision making by husband and wife while buying household assets

\begin{tabular}{|c|c|c|c|c|c|c|c|c|}
\hline \multirow{3}{*}{ Assets } & \multicolumn{8}{|c|}{ Mean size } \\
\hline & \multicolumn{2}{|c|}{ All respondents } & \multicolumn{3}{|c|}{ Wife (PDM) } & \multicolumn{3}{|c|}{ Husband (PDM) } \\
\hline & Before & After & Before & After & $\%$ change & Before & After & $\%$ change \\
\hline Bicycle & 0.68 & 1.16 & 0.64 & 1.10 & 71.88 & 0.63 & 1.17 & 85.71 \\
\hline Television & 0.50 & 1.02 & 0.45 & 1.00 & 122.22 & 0.33 & 1.00 & 203.03 \\
\hline Almirah & 0.82 & 1.30 & 0.73 & 1.27 & 73.97 & 0.67 & 1.13 & 68.66 \\
\hline Chair-table & 4.44 & 6.78 & 4.70 & 7.82 & 66.38 & 3.96 & 6.17 & 55.81 \\
\hline Chanki/khat & 2.70 & 3.40 & 2.70 & 3.36 & 24.44 & 2.71 & 3.46 & 27.67 \\
\hline $\begin{array}{l}\text { Sewing } \\
\text { machine }\end{array}$ & 0.14 & 0.52 & 0.10 & 0.73 & 630.00 & 0.08 & 0.50 & 525.00 \\
\hline Dining table & 0.12 & 0.52 & 0.09 & 0.64 & 611.00 & 0.08 & 0.42 & 425.00 \\
\hline Show-case & 0.58 & 0.98 & 0.64 & 1.00 & 56.25 & 0.46 & 0.92 & 100.0 \\
\hline Electric fan & 1.20 & 2.36 & 1.45 & 2.64 & 82.07 & 1.13 & 2.21 & 95.57 \\
\hline Mobile phone & 0.02 & 0.84 & - & 0.91 & - & - & 0.96 & - \\
\hline Land (hector) & 0.27 & 0.30 & 0.27 & 0.28 & 3.70 & 0.29 & 0.31 & 6.89 \\
\hline
\end{tabular}

expand their farming activities and improve their status.

\section{Conclusion}

Small scale broiler farming has created opportunities of work for unemployed family members and generated household income for the farmers. Women's participation in the decision making process on issues concerning the education of their children, the planning of household expenditure, the marriage of a son or daughter, or the purchase of necessary household assets have increased after their successful involvement in broiler farming. The participation of women in decision making processes concerning the various aspects of the household, and increased confidence on their abilities to make decisions, are often considered good indicators of their status and power within the family and society. Therefore, it can be said that small scale broiler farming has contributed positively to the socio-economic development of the broiler farmers. It created an opportunity for the women to participate in the income generating activity of their families. Thus, their contribution to the family has increased. This is likely to increase their importance and improve their self-esteem and self-confidence in all matters. Moreover, it could be argued that the imbalance with respect to the low status of women relative to men may well be corrected if they provide labor through participation in broiler rearing and contribute to family welfare. Thus, broiler farming through participation of women serves to increase their family income and is likely to be accorded greater recognition and higher social value. Women's labor is more highly valued when it is accorded social prestige and provides support services that increase its economic returns.

\section{References}

[1] S. Ahmed, "Backyard Poultry Development Project (BPDP)", Sponsored by UNICEF, personal communication principle investigator of the project BPDP, Bangladesh Agricultural University, (Mymensingh: Bangladesh 2008).

[2] T. K. Biswas, Women's empowerment and demographic change, Bangladesh Academy for Rural Development, (Comilla, Bangladesh, (2004.)

[3] DLO (District Livestock Research), "Report on poultry," (Mymensingh: Bangladesh, 2008).

[4] DLS (Department of Livestock Services), “Activities at a glance" (Dhaka: Bangladesh, 2006-2007).

[5] H. Nielsen, Participatory livestock development project- Bangladesh. Fifth Mission Report to DANIDA, (2003).

[6] S. K. Raha, "Broiler industry in Bangladesh: some issues," In: proceedings of the $5^{\text {th }}$ International Poultry Show and Seminar, Organized by World's Poultry Science Association, Bangladesh Branch, Dhaka, Bangladesh, from March 01-03, 2007.

[7] M. A. Saleque, "Poultry industry in Bangladesh: current status and its future," Poultry business directory, Poultry Khamar Bichitra, Dhaka, Bangladesh, (2006). 